\title{
Socio Economic Profile of Buffalo Farmers in Patan Districts of Gujarat, India
}

\author{
N.S. Patel, J.V. Patel*, D.V. Parmar, V.K. Patel, N.K. Thakkar, \\ M.P. Madhavatar and R.K. Prajapati
}
College of Veterinary Science and Animal Husbandry, Sardarkrushinagar Dantiwada Agriculture University, Gujarat, India

*Corresponding author

\section{A B S T R A C T}

Keywords

Gujarat, Mahesana buffalo, Patan district, Socio economic

\section{Article Info}

Accepted:

17 November 2018 Available Online:

10 December 2018
A field study was undertaken to find out the shelter management practices followed by the farmers of Patan district of North Gujarat region. Five talukas were randomly selected for the study viz., Patan, Sidhpur, Chanasma, Harij and Santalpur. Three villages were selected from each taluka and from each village 10 respondents who reared buffalo either alone or mixed with cattle were selected by using a multistage random sampling technique. The analyses revealed that majority $(58.00 \%)$ of the respondents were from the old age group (above 45 yrs.). The low literacy level of animal keepers forced them to adopt the animal husbandry profession as $87.34 \%$ respondents were either illiterate $(50.00 \%)$ or low literate $(37.34 \%)$. Half $(58.00 \%)$ of the farmers were from medium size family (5 to 8 members), and small herd size $(32.00 \%)$ of less than 5 animals. $55.33 \%$ respondents had medium herd size (4 to 6 animals). Most of the respondents $(79.33 \%$ ) adopted intensive type of buffalo husbandry system.

\section{Introduction}

Buffalo holds the greatest promise for food security in the $21^{\text {st }}$ century as these animals form an integral part of the typical farming system in many regions of India. Buffalo is the largest capital asset as well as the friend of small farmers which is the back bone of rural economy in many parts of India.

Buffaloes are well adapted to the hot and humid climate of India and play a distinct role in improving the rural economy which is primarily based on agricultural production systems. Livestock housing conditions and all animal husbandry practices exert a considerable influence on animal behaviour, health and production. Integrating various aspects such as improved housing, nutrition, breeding and milking together are known to produce remarkable improvements in growth, reproduction and production performance. In planning and designing of suitable housing accommodation for dairy cattle, consideration should be given to the comfort and health of the animals along with economic use of labour for various dairy farm operations like feeding, cleaning, milking and maintenance of farm sanitation etc. 
Dairy farming plays a very important role in improving the economy of the country. Milk has an important place in human diet. Milk production in India is predominantly the domain of small holders in mixed farming system. Indian dairying has made rapid strides, but animal productivity remained low, average dairying assumes great significance in providing employment to rural people as well as a stable source of income to augment to their earnings from main enterprise they follow i.e. crop husbandry. Dairy enterprise plays a very important role in the rural Economy of India. It provides income and employment not only to the workers sections of the society but also to the farming community of the country in general. The return from small holdings can be maximized by the proper combination of dairy enterprise with crop production. India ranks first in number of animals and in production of milk in the world. India succeeded in producing 88.1 million tons of milk to become world's largest milk producer.

\section{Materials and Methods}

The present study was carried out in villages of patan districts of Gujarat state. It was selected due to presence of large number of buffaloes, buffalo rearing farmers, familiarity of researcher with the area and local language and his ability to cover larger area within stipulated time. Five talukas from patanvizPatan, Sidhpur, Chanasma, Harij and Santalpur were selected and from each selected taluka 3 villages were chosen randomly. In each village 10 farmers were selected. Thus samples of 150 buffalo owners were selected for the study. While selecting respondents due cares was taken to ensure that they were evenly distributed in the village and were a true representative of animal management practices prevailing in the area the selected respondents were interviewed personally and information was collected with the help of predesigned questionnaire The variables under study were selected on the basis of extensive review of literature related to the topic of research and consultation with experts.

\section{Results and Discussion}

\section{Age}

Age was an important factor, which influences the behavior pattern of an individual. The maximum \% of the dairy buffalo keepers $(58.00 \%)$ belonged to old age category followed by young $(2.67 \%)$ and middle $(39.33 \%)$ in the Patan district. Santalpurtaluka had maximum $(83.33 \%)$ respondents of old age followed by Harijtaluka $(73.33 \%)$. Respondents of middle age group were highest $(60.00 \%)$ in Siddhapurtaluka followed by Patan (53.33\%) and Chanasmataluka $(40.00 \%)$. Data indicated that the old age group had more responsibility with better experience and interest, so they were always ready to adopt new innovations without considering the reaction of the other ones. It was noteworthy fact that the young generation had no interest in buffalo keeping in the district as their proportion is very low $(2.67 \%)$. Some in the trend observed in different talukas.

The present finding was well supported by the result of earlier workers, (Gill and Saini 2008). However, there was a lot of variation in findings and they were indicative of differences in accordance with the overall demographic structure of the regions.

\section{Education}

Education is essential to understand and to adopt new technology by the farmers. The level of education of dairy buffalo owners was studied and it was observed that half of the respondents $(50.00 \%)$ were illiterate, while 
37.34, 9.33 and $3.33 \%$ respondents had education of primary, secondary and college level, respectively in Patan district. Trend for education level was significantly $(\mathrm{p}<0.01)$ differed with talukas. Illiterate respondents were highest in Santalpurtaluka (73.33\%), followed by Harij $(50.00 \%)$ and Patan,Chanasma (43.33\%). Literacy rate was better in Sidhpur and Chanasmataluka due to more education facilities in these talukas.

The present finding was comparable with the finding of earlier workers (Bardoloi et al., 2005) as they stated that $44.57 \%$ dairy households were illiterate whereas educated up to $10^{\text {th }}$ standard and above $10^{\text {th }}$ standard were $42.33 \%$ and $13.11 \%$, respectively in their study area.

\section{Family size}

In modern era the concept of small family is well recognized for better welfare of family. The family size was measured on the basis of total number of members residing with the respondent.

The perusal of data presented in revealed that majority of respondents had medium size family $(58.00 \%)$ followed by large size $(33.33 \%)$ and small size $(8.67 \%)$ respectively. Family size was differed significantly among talukas. Similar trend was observed by earlier workers (Siddiki et al., 2015) as they showed that $43.89 \%$ respondents had medium, 32.78 $\%$ had large and $23.33 \%$ had small family size in their study area.

Santalpur and Harijtalukas had more families with large size, while Patan, Chanasma and Sidhpur had more families with medium size categories. More numbers of families of medium and big size which was due to more numbers of children and joint families. Adoption of family planning was very low due to illiteracy and low level of education.

\section{Size of land holding}

Land holding is essential to support the animal husbandry activities. The information regarding land holding capacity of the respondent was collected and is presented in table 1. The observations of present study made it clear that the majority of respondents $(43.33 \%)$ were falling under medium land holdings followed by marginal (22.67\%), small $(21.33 \%)$ and large land holding $(12.67 \%)$ in the Patan district. Trend for land holding size was differed significantly among talukas. This finding year more or less coincides with the finding of Modi (2003), Sivaji et al., (2018) in Sabarkantha district and Soni (2005) in Mehsana district. Santalpur taluka had highest numbers of marginal farmers $(70.00 \%)$, while medium farmers were more in Chanasma, Sidhpur and Harijtalukas.

\section{Herd size}

Herd size was grouped according to pilot survey and based on trend observed in the district. The term herd size indicates the number of dairy buffaloes kept by individual respondent. The information collected from respondents was grouped into four categories based on the number of dairy buffaloes kept by them. It is apparent from table 1 that majority of the respondents $(55.33 \%)$ had medium herd size followed by small $(32.00 \%)$ and large size herd (12.67\%) in Patan district. Majority of the farmers had small and medium size herd as they had marginal to small land holding so they could not allocate more area for fodder production. The price of dairy buffalo was also very high. Trend for herd size was not differed significantly among talukas. This finding is well supported by that of Shinde et al., (1998) as they reported in Udgir block of Osmanabad district of Maharashtra, majority of the respondents (60.83\%) possessed up to 4 animals followed by 5 to 8 animals $(20.00 \%)$. 
Table.1 Distribution of the buffalo owners according to socio economic profile $(\mathrm{n}=150)$

\begin{tabular}{|c|c|c|c|c|c|c|c|c|}
\hline Sr. No & Particulars & Patan & Sidhpur & Chanasma & Harij & Santalpur & Total & Chi Square Value \\
\hline \multirow[t]{4}{*}{1} & \multicolumn{8}{|l|}{ Age } \\
\hline & Young age (Up to 30 years) & $\begin{array}{l}2 \\
(6.67)\end{array}$ & $\begin{array}{l}1 \\
(3.33)\end{array}$ & $\begin{array}{l}1 \\
(3.33)\end{array}$ & $\begin{array}{l}0 \\
(0.00)\end{array}$ & $\begin{array}{l}0 \\
(0.00)\end{array}$ & $\begin{array}{l}4 \\
(2.67)\end{array}$ & \multirow{3}{*}{$21.97 * *$} \\
\hline & Middle age ( 31 to 45 years) & $\begin{array}{l}16 \\
(53.33)\end{array}$ & $\begin{array}{l}18 \\
(60.00)\end{array}$ & $\begin{array}{l}12 \\
(40.00)\end{array}$ & $\begin{array}{l}8 \\
(26.67)\end{array}$ & $\begin{array}{l}5 \\
(16.67)\end{array}$ & $\begin{array}{l}59 \\
(39.33)\end{array}$ & \\
\hline & Old age (above 45 years) & $\begin{array}{l}12 \\
(40.00)\end{array}$ & $\begin{array}{l}11 \\
(36.67)\end{array}$ & $\begin{array}{l}17 \\
(56.67)\end{array}$ & $\begin{array}{l}22 \\
(73.33)\end{array}$ & $\begin{array}{l}25 \\
(83.33)\end{array}$ & $\begin{array}{l}87 \\
(58.00)\end{array}$ & \\
\hline \multirow[t]{5}{*}{2} & \multicolumn{8}{|l|}{ Education } \\
\hline & Illiterate & $\begin{array}{l}13 \\
(43.34)\end{array}$ & $\begin{array}{l}12 \\
(40.00)\end{array}$ & $\begin{array}{l}13 \\
(43.33)\end{array}$ & $\begin{array}{l}15 \\
(50.00)\end{array}$ & $\begin{array}{l}22 \\
(73.33)\end{array}$ & $\begin{array}{l}75 \\
(50.00)\end{array}$ & \multirow[t]{4}{*}{$23.72 * *$} \\
\hline & $\begin{array}{l}\text { Primary } \\
\left(1-7^{\text {th }} \text { std. }\right)\end{array}$ & $\begin{array}{l}13 \\
(43.33)\end{array}$ & $\begin{array}{l}15 \\
(50.00)\end{array}$ & $\begin{array}{l}8 \\
(26.67)\end{array}$ & $\begin{array}{l}12 \\
(40.00)\end{array}$ & $\begin{array}{l}8 \\
(26.67)\end{array}$ & $\begin{array}{l}56 \\
(37.34)\end{array}$ & \\
\hline & $\begin{array}{l}\text { Secondary } \\
\left(8-12^{\text {th }} \text { std. }\right)\end{array}$ & $\begin{array}{l}3 \\
(10.00)\end{array}$ & $\begin{array}{l}1 \\
(3.33)\end{array}$ & $\begin{array}{l}8 \\
(26.67)\end{array}$ & $\begin{array}{l}2 \\
(6.67)\end{array}$ & $\begin{array}{l}0 \\
(0.00)\end{array}$ & $\begin{array}{l}14 \\
(9.33)\end{array}$ & \\
\hline & College $\left(12^{\text {th }}\right.$ and above $)$ & $\begin{array}{l}1 \\
(3.33)\end{array}$ & $\begin{array}{l}2 \\
(6.67)\end{array}$ & $\begin{array}{l}1 \\
(3.33)\end{array}$ & 1 & $\begin{array}{l}0 \\
(0.00)\end{array}$ & $\begin{array}{l}5 \\
(3.33)\end{array}$ & \\
\hline \multirow[t]{4}{*}{3} & Family Size & & & & & & & \\
\hline & $\begin{array}{l}\text { Small size } \\
\text { (up to } 4 \text { members) }\end{array}$ & $\begin{array}{l}3 \\
(10.00)\end{array}$ & $\begin{array}{l}5 \\
(16.67)\end{array}$ & $\begin{array}{l}5 \\
(16.67)\end{array}$ & $\begin{array}{l}0 \\
(0.00)\end{array}$ & $\begin{array}{l}0 \\
(0.00)\end{array}$ & $\begin{array}{l}13 \\
(8.67)\end{array}$ & \multirow[t]{3}{*}{$94.60 * *$} \\
\hline & $\begin{array}{l}\text { Medium size } \\
\text { (5-8 members) }\end{array}$ & $\begin{array}{l}27 \\
(90.00)\end{array}$ & $\begin{array}{l}23 \\
(76.67)\end{array}$ & $\begin{array}{l}24 \\
(80.00)\end{array}$ & $\begin{array}{l}8 \\
(26.67)\end{array}$ & $\begin{array}{l}5 \\
(16.67)\end{array}$ & $\begin{array}{l}87 \\
(58.00)\end{array}$ & \\
\hline & $\begin{array}{l}\text { Large size } \\
\text { (more than } 8 \text { members) }\end{array}$ & $\begin{array}{l}0 \\
(0.00)\end{array}$ & $\begin{array}{l}2 \\
(6.66)\end{array}$ & $\begin{array}{l}1 \\
(3.33)\end{array}$ & $\begin{array}{l}22 \\
(73.33)\end{array}$ & $\begin{array}{l}25 \\
(83.33)\end{array}$ & $\begin{array}{l}50 \\
(33.33)\end{array}$ & \\
\hline \multirow[t]{5}{*}{4} & \multicolumn{8}{|l|}{ Size of Land Holding } \\
\hline & $\begin{array}{l}\text { Marginal farmer } \\
(>2.5 \text { Acres })\end{array}$ & $\begin{array}{l}3 \\
(10.00)\end{array}$ & $\begin{array}{l}3 \\
(10.00)\end{array}$ & $\begin{array}{l}3 \\
(10.00)\end{array}$ & $\begin{array}{l}4 \\
(13.33)\end{array}$ & $\begin{array}{l}21 \\
(70.00)\end{array}$ & $\begin{array}{l}34 \\
(22.67)\end{array}$ & \multirow[t]{4}{*}{$55.89 * *$} \\
\hline & $\begin{array}{l}\text { Small farmer } \\
(2.5-5 \text { Acres })\end{array}$ & $\begin{array}{l}8 \\
(26.67)\end{array}$ & $\begin{array}{l}8 \\
(26.67)\end{array}$ & $\begin{array}{l}4 \\
(13.33)\end{array}$ & $\begin{array}{l}6 \\
(20.00)\end{array}$ & $\begin{array}{l}6 \\
(20.00)\end{array}$ & $\begin{array}{l}32 \\
(21.33)\end{array}$ & \\
\hline & $\begin{array}{l}\text { Medium farmer } \\
\text { (5-10 Acres) }\end{array}$ & $\begin{array}{l}13 \\
(43.33)\end{array}$ & $\begin{array}{l}16 \\
(53.33)\end{array}$ & $\begin{array}{l}19 \\
(63.34)\end{array}$ & $\begin{array}{l}15 \\
(50.00)\end{array}$ & $\begin{array}{l}2 \\
(6.67)\end{array}$ & $\begin{array}{l}65 \\
(43.33)\end{array}$ & \\
\hline & $\begin{array}{l}\text { Large farmer } \\
\text { (>10 Acres) }\end{array}$ & $\begin{array}{l}6 \\
(20.00)\end{array}$ & $\begin{array}{l}3 \\
(10.00)\end{array}$ & $\begin{array}{l}4 \\
(13.33)\end{array}$ & $\begin{array}{l}5 \\
(16.67)\end{array}$ & $\begin{array}{l}1 \\
(3.33)\end{array}$ & $\begin{array}{l}19 \\
(12.67)\end{array}$ & \\
\hline \multirow[t]{4}{*}{5} & \multicolumn{8}{|l|}{ Herd Size } \\
\hline & $\begin{array}{l}\text { Small } \\
\text { (1-3 animals) }\end{array}$ & $\begin{array}{l}11 \\
(36.67)\end{array}$ & $\begin{array}{l}9 \\
(30.00)\end{array}$ & $\begin{array}{l}8 \\
(26.67)\end{array}$ & $\begin{array}{l}11 \\
(36.67)\end{array}$ & $\begin{array}{l}9 \\
(30.00)\end{array}$ & $\begin{array}{l}48 \\
(32.00)\end{array}$ & \multirow[t]{3}{*}{7.0} \\
\hline & $\begin{array}{l}\text { Medium } \\
\text { (4-6 animals) }\end{array}$ & $\begin{array}{l}15 \\
(50.00)\end{array}$ & $\begin{array}{l}15 \\
(50.00)\end{array}$ & $\begin{array}{l}16 \\
(53.33)\end{array}$ & $\begin{array}{l}18 \\
(60.00)\end{array}$ & $\begin{array}{l}19 \\
(63.33)\end{array}$ & $\begin{array}{l}83 \\
(55.33)\end{array}$ & \\
\hline & $\begin{array}{l}\text { (Large } \\
(6-10 \text { animals) }\end{array}$ & $\begin{array}{l}4 \\
(13.33)\end{array}$ & $\begin{array}{l}6 \\
(20.00)\end{array}$ & $\begin{array}{l}6 \\
(20.00)\end{array}$ & $\begin{array}{l}1 \\
(3.33)\end{array}$ & $\begin{array}{l}2 \\
(6.67\end{array}$ & $\begin{array}{l}19 \\
(12.67)\end{array}$ & \\
\hline \multirow[t]{4}{*}{6} & \multicolumn{8}{|l|}{ Type of Animal Husbandry } \\
\hline & Extensive & $\begin{array}{l}0 \\
(0.00)\end{array}$ & $\begin{array}{l}0 \\
(0.00)\end{array}$ & $\begin{array}{l}1 \\
(3.33)\end{array}$ & $\begin{array}{l}0 \\
(0.00)\end{array}$ & $\begin{array}{l}15 \\
(50.00)\end{array}$ & $\begin{array}{l}16 \\
(10.67)\end{array}$ & \multirow[t]{3}{*}{$89.63 * *$} \\
\hline & Semi intensive & 1 & $\begin{array}{l}0 \\
(0.00)\end{array}$ & 1 & 4 & $\begin{array}{l}9 \\
(30.00)\end{array}$ & $\begin{array}{l}15 \\
(10.00)\end{array}$ & \\
\hline & Intensive & $\begin{array}{l}29 \\
(96.67)\end{array}$ & $\begin{array}{l}30 \\
(100.00)\end{array}$ & $\begin{array}{l}28 \\
(93.33)\end{array}$ & $\begin{array}{l}26 \\
(86.66)\end{array}$ & $\begin{array}{l}6 \\
(20.00)\end{array}$ & $\begin{array}{l}119 \\
(79.33)\end{array}$ & \\
\hline
\end{tabular}

** $\mathrm{P} \leq 0.01$ percentages are mentioned without bracket (Frequencies are mentioned in bracket)

More acceptance of medium herd size was and fodder from their own land. due to easy handling proper utilization of feed 


\section{Type of animal husbandry}

From data in Table 1, regarding type of animal husbandry, it was evident that majority farmers (79.33\%) adopted intensive system for rearing in which buffaloes tied for all the time under shed and no time allow for grazing $10.00 \%$ respondents adopted semi intensive type of system in which buffaloes grazed partially during day time and partially stall fed and $10.67 \%$ farmers adopted extensive type of system due to availability of grazing land and lack of infrastructure. Trend for type of animal husbandry was differed significantly $(\mathrm{p}<0.05)$ among talukas. Among all the talukas extensive system $(50.00 \%)$ was more prevalent in Santalpurtaluka as the agriculture is of rainfed with least irrigation facilities. Proportion of marginal farmers is highest adopted grazing more in the taluka. Intensive system was better prevalent in Sidhpur, Patan, Chanasma and Harijtalukas due to more proportion of medium and large farmers and irrigation facilities. This finding is more or less supported by Gelot (2012) as he observed similar pattern in Banaskantha district.

In conclusion considering all the studied parameters, buffalo rearing was a profitable practice in the selected areas and improve the socio-economic status of buffalo farmers.

\section{References}

Bordoloi, J. P., Laskar, S. K., Haque, A. and Bora, N.N. $2005 . \quad$ Socio-economic characteristics of dairy households of Guwahati in Assam. Indian Veterinary Journal. 82: 427-429.

Gelot U. V. 2012.Study of shelter management for buffalo in Banaskantha district of North Gujarat. M.V.Sc. thesis, S.D.A.U., Sardarkrushinagar, India.

Gill, T. K. and Saini, S. K. 2008. A study of awareness of recommended dairy practices among farmers. International journal of Agricultural Science.4 (1): 296300.

Modi, R. J. 2003. Study of animal managemental practices in Sabarkantha district of North Gujarat. M.V.Sc. thesis, S.D.A.U., Sardarkrushinagar, India.

Shinde, V. G., Sangle, G. K. and Dikle, R. N. 1998. Factors associated with adoption of dairy practices by farmers. Maharashtra Journal of Extension Education.17:108 117.

Siddiki, M. A., Amin, M. R., Kabir, A. K., Faruque, M. O. and Khandaker, Z. H. 2015. Socio-economic status of buffalo farmers and the performances of buffaloes at Lalpur Upozila of Natore district in Bangladesh. Bangladesh Journal of Animal Science. 44(3):157-165.

Sivaji, D.V., K. Natchimuthu, S., Ramkumar, D., Sreekumar and Ganesan, R., 2018. Socio Economic Profile of Buffalo Farmers in Guntur and Prakasam Districts of Andhra Pradesh, India. International Journal of Current Microbiology and Applied Science. 7(4): 1950-1955.

Soni, A. 2005. Study of animal managemental practices in Mehsana district of North Gujarat. M.V.Sc. thesis, S.D.A.U., Sardarkrushinagar, India.

\section{How to cite this article:}

Patel, N.S., J.V. Patel, D.V. Parmar, V.K. Patel, N.K. Thakkar, M.P. Madhavatar and Prajapati, R.K.. 2018. Socio Economic Profile of Buffalo Farmers in Patan Districts of Gujarat, India. Int.J.Curr.Microbiol.App.Sci. 7(12): 2352-2356. doi: https://doi.org/10.20546/ijcmas.2018.712.266 